\title{
İş Tatmininin Örgütsel Stres Algısına Etkisi: Cinsiyet ve Medeni Durumun Düzenleyici Rolü
}

\author{
Pınar ERDOĞAN* (D)
}

\begin{abstract}
ÖZ
$\mathrm{Bu}$ araştırmanın amacı iş tatminin algılanan örgütsel stres etkisinde akademisyenlerin cinsiyetinin ve medeni durumunun düzenleyici rolünü belirlemektir. Örgütsel stres, çalışanın örgüt politikalarından kaynaklı yaşadığı stres, iş tatmini ise bireyin işinden duyduğu hoşnutluk hali olarak tanımlanabilmektedir. Nicel araştırma yöntemi kullanılan çalışmada veriler anket tekniğgi ile toplanmıştır. Çalışmanın evren (N:668) ve örneklemini (n: 261) Karamanoğlu Mehmetbey Üniversite'nde görev yapan akademisyenler oluşturmaktadır. Elde edilen verilerin yapısal geçerliliğini tespit etmek için normallik analizi, keşfedici faktör analizi ve güvenirlik analizi yapılmıştır. Araştırmanın hipotezleri Hayes tarafından geliştirilen Process Macro (SPSS için) programı kullanılarak analiz edilmiş ve yorumlanmıştır. Yapılan analizler sonucunda iş tatmininin örgütsel stres algısı üzerindeki negatif etkisi kadın ve erkek akademisyenlere göre farklılık göstermekte ve hem kadın hem de erkek akademisyenlerde iş tatmini örgütsel stres algısını etkilemektedir. Ancak kadın akademisyenlerin erkek akademisyenlere göre iş tatminlerinin örgütsel stres algiları üzerindeki negatif etkisi daha güçlü olarak bulgulanmıştır. İkinci olarak iş tatmininin örgütsel stres algisı üzerindeki negatif etkisi evli ve bekar akademisyenlere göre farklılık gösterdiği bulgulanmıștır. Evli akademisyenlerin iș tatminleri örgütsel stres algısını anlamlı şekilde etkilerken bekar akademisyenlerde bu etki anlamlı değildir. Araştırmada elde edilen bulgulara göre akademisyenlerin iş tatminlerinin örgütsel stres alg1lan üzerinde etkisinde cinsiyet ve medeni durumun düzenleyicilik etkisi bulunmaktadır. Ancak kadınların iş tatmin düzeyleri örgütsel stres algılarını erkeklere nazaran daha yüksek düzeyde etkilemektedir. Evli akademisyenlerin iş tatminleri örgütsel stres alg1larını etkilerken bekar akademisyenlerin iş tatminleri örgütsel stres algılarını etkilememektedir.
\end{abstract}

Anahtar Kelimeler: İş Tatmini, Örgütsel Stres, Cinsiyet, Medeni Durum.

\section{The Effect of Job Satisfaction on Perception of Organizational Stress: The Regulatory Role of Gender and Marital Status}

\begin{abstract}
The purpose of this study is to determine the regulatory role of the gender and marital status of academicians in the perceived organizational stress effect of job satisfaction. Organizational stress can be defined as the stress experienced by the employee due to organizational policies, and job satisfaction can be defined as the individual's satisfaction with his/her job. In the study, in which quantitative research method was used, data were collected by questionnaire technique. The universe (N: 668) and the sample (n: 261) of the study consist of the academicians working at Karamanoğlu Mehmetbey University. Normality analysis, exploratory factor analysis and reliability analysis were performed to determine the structural validity of the data obtained. The hypotheses of the study were analyzed and interpreted using the Process Macro (for SPSS) program developed by Hayes. As a result of the analysis, the negative effect of job satisfaction on the perception of organizational stress differs according to male and female academicians, and job satisfaction affects the perception of organizational stress in both female and male academicians. However, the negative effect of job satisfaction on organizational stress perceptions of female academicians was found to be stronger than male academicians. Secondly, the negative effect of job satisfaction on the perception of organizational stress differs according to married and single academicians. While job satisfaction of married academics significantly affects the perception of organizational stress, this effect is not significant for single academicians. According to the findings of the study, gender and marital status have a regulatory effect on the effect of academicians' job satisfaction on their perceptions of organizational stress. However, while job satisfaction levels of women affect perceptions of organizational stress at a higher level than men, job satisfaction of married academicians affects their perception of organizational stress, while job satisfaction of single academicians does not affect their perception of organizational stress.
\end{abstract}

Keywords: Job Satisfaction, Organizational Stress, Gender, Marital Status

\section{Kavramsal Çerçeve ve Hipotezler}

1.1. İş Tatmini Kavramı

Çalışanın bir işi yaparken elde ettiği zevki ifade eden iş tatmini (Asghar \& Oino, 2017) ile ilgili araşturmaların yönetim disiplinine girişi Hawthorne çalışmalarıyla olmuştur (Locke, 1969; Kim, Tavitiyaman \& Kim, 2009). Sosyal bilimler alanında ilk kez Hoppock (1935) tarafindan tanıtılan iş tatmini; kişinin işinden memnun olduğunu söylemesine neden olan psikolojik, fizyolojik ve çevresel koşulların toplamı olarak tanımlanmıştır (Dar \& Najar, 2017).

* Dr. Öğretim Üyesi, Karamanoğlu Mehmetbey Üniversitesi, perdogan@kmu.edu.tr Makalenin Gönderim Tarihi: 23.11.2020; Makalenin Kabul Tarihi: 11.02.2021 
İş tatmini ile ilgili en çok atıf alan tanımı yapan Locke ( 1976) iş tatminini; kişinin işini değerlendirirken hissettiği olumlu ve duygusal durum olarak tanımlamıştır (Dar \& Najar, 2017). İş tatminin nedeni konusunda (iş kaynaklımı, çalışan kaynaklı mı yoksa çevre kaynaklımı) netlik olmadığı düşüncesinden yola çıkan Locke 1963 yılında bireyin işini sevmesi ile iş tatmini arasındaki ilişkiyi araştırmaya başlamıştır. Bu ilişkiyi araştırdığ1 8 çalışmadan 7'sinde işini seven bireylerin iş tatmininin daha yüksek olduğunu bulgulamıştır (Locke, 1969). Bu sonuca göre bireylerde iş tatmini etkileyen en önemli etkenlerden biri bireyin işine duyduğu sevgi olarak ortaya konulmuştur.

İş tatmini, işin niteliği ne olursa olsun bir çalışanın performansını ve etkinliğini artıran (Wright, 2006; Dar \& Najar, 2017) bir unsur olması ve iş tatmini düşüklügünün işletme çalışma koşullarının bozulduğunu gösteren en önemli işaret olması (Y1lmazer, 2019, s. 284) sebebiyle geçmişte olduğu gibi günümüzde de en çok araştırlan konulardan biri olmaya devam etmektedir. Alegre Mas-Machuca ve Berbegal-Mirabent, (2016)' e göre iş tatmini etkileyen üç temel ilişki vardır. Bunlar; çalışan-organizasyon ilişkisi, çalışan-yönetici ilişkisi ve çalışan-iş arkadaşı ilişskisidir. İş tatminini etkileyen ilk ilişki tipi olan çalışan ile organizasyon arasındaki ilişkiyi güçlendirmek için örgütler öncelikle hedeflerini net olarak belirlemelidir. Çünkü bireylerin iş tatmini belirleyicilerinden biri olan örgüte bağll1ıkları ancak örgüt hedeflerini benimsemeleri sonucunda sağlanabilecektir. Hedeflerin belirlenmesi ve çalışanla özdeşleşmesinin ardından bu hedeflere ulaşmada yöneticinin verdiği destek diğer bir iş tatmini belirleyicisidir. Yöneticinin çalışana sağladığı destek oranında çalışanın iş tatmini artacak ya da azalacaktır. İş tatminini etkileyen son ilişki şekli ise çalışan ve iş̧ arkadaşları arasındadır. Bu bağlamda örgütlerin ekip çalışmasını ve gruplar arası işbirliğini artırmaya yönelik düzenlemeleri yine iş tatminine olumlu sonuçlar doğuracaktır.

Duygusal ve kişisel bir kavram olan iş tatmininin (İşcan ve Sayın, 2010: 198) bu özelliği her çalışanda aynı düzeyde tatmin sağlayacak net faktörlerin olmadığı anlamına gelmektedir. Çalışanların iş tatminini etkileyen faktörleri bireysel ve örgütsel faktörler olarak ikiye ayıran Çimen ve Deniz (2019, ss. 76-78), cinsiyet, yaş, eğitim durumu, statü ve kişiliği bireysel faktörler olarak belirtirken, örgütsel faktörler olarak; örgütün fiziksel koşullanı, örgütün işleyiş ve politikalanı, ücret, yükselme olanaklanı ve işin niteliği gibi faktörlerin iş tatmini etkilediğini belirtmiştir. Bu etkilerle paralel olarak işin çekici bir yapısının olması, işyerinde iletişim kurma firsatlarının varlığı, işin kişiye özerklik tanıması, gelişme firsatı vermesi, iş güvencesinin olması, takdir edilme, esnek çalışma ve düzenli çalışma saati firsatlarının varllğı çalışanlarının iş tatminlerini artırıcı etki yaratan unsurlar olarak karşımıza çıkmaktadır (Zencirkıran \& Keser, 2018, ss. 102-118).

\subsubsection{Cinsiyet ve Medeni Durum Değişkenleriyle İş Tatmini İlişkisi}

Cinsiyet ve medeni durum iş tatmini etkileyen bireysel faktörler arasında yer alan değişkenlerden ikisi olarak karşımıza çıkmaktadır (Özpehlivan, 2018, s. 49). Nitekim bu durum farklı sektörlerde yapılan çalışmalarla da ortaya konulmuştur. Ancak bu çalışma sonuçlarında iş tatmininin cinsiyet ve medeni duruma göre farklılaşıp farklılaşmadığına dair bir tutarlıık bulunmamaktadır. Bu çalışmalardan biri Mosadeghrad ve Yarmohammadian (2006) tarafindan İran sağlık sektöründe 814 çalışan ile yapilmıştır. Çalışma sonucunda erkek sağlık çalışanların iş tatmini puanları kadınlara göre anlamlı şekilde yüksek bulgulanırken, bekar sağlık çalışanlarının iş tatmini düzeyleri evli çalışanlardan anlamlı şekilde düşük olarak bulgulanmıştır.

Kadınların iş dünyasında ayrımcıllğa uğradığı iddia edilmesine rağmen önceki araştırmaların çoğunda kadınların iş tatmin düzeylerinin erkeklerden daha yüksek bulgulandığını belirten Sloane ve Williams (2000) iş tatmininde cinsiyet farklılıklarını araştırdıkları çalışmalarında yine kadınların iş tatmin düzeylerini erkeklerden daha yüksek olarak bulgulamışlardır. Bender vd. (2005) yine kadınlann iş tatmin düzeylerinin erkeklere göre daha yüksek olduğunu bulgulamışlardır. Azim vd. (2013) ise Bangladeş'teki çalışanların iş tatmini düzeyinin cinsiyet ve medeni durum açısından farkl1lık gösterip göstermediğini test ettikleri çalışmalarında, cinsiyet ve medeni durumunun iş tatmin düzeyini anlamlı şekilde farklılaşırmadığını bulgulamışlardır. Saner ve Eyüpoğlu (2013) akademisyenlerle yaptıkları çalışmalarında iş tatminini evli akademisyenler lehine bulgulanmışlardır. Sevimli ve İşcan'ın (2005) yaptığı çalışmada yine evli doktorların iş tatmini düzeylerinin daha yüksek olduğu bulgulanmışır. 
67 akademisyen üzerinde iş tatmininin cinsiyete göre farklılaşıp farklılaşmadığını araştıran Aşan ve Erenler (2008) araştırma sonucunda, kadın ve erkek akademisyenlerin iş tatminlerinin cinsiyetlerine göre farklılaşmadığını bulgulamışlardır. Sınıf ve branş öğretmen örneklemli çalışmasında Karataş ve Güleş (2010), benzer şekilde öğretmenlerin iş tatmin düzeylerinin cinsiyetlerine göre farklılaşmadığını bulgulamıştır. Bozkurt ve Bozkurt (2008) eğitim sektöründe yaptığı çalışma sonucunda yine çalışanların kadın yada erkek olmalarının iş tatminlerini etkilemediğini ortaya koymuştur.

İş tatmininin Türkiye ve Kazakistan'da çalışan öğretmenlerin performans düzeyleri ile olan ilişkisini ortaya koymaya amaçladığı çalışmasında Yazıcıoğlu (2010) hem Türkiye'de hem de Kazakistan'da çalışan öğretmenlerin iş tatmin düzeylerinin cinsiyetlerine göre anlamlı şekilde farklılaştğ̆ını ve kadın öğretmelerin iş tatmin düzeylerinin erkek öğretmenlerden daha yüksek olduğunu bulgulamıştır. Beden eğitimi öğretmenlerinde iş tatminin cinsiyete göre farklılı̆̆ını araştıran Can ve Soyer (2008) iş tatmini düzeylerinin yine kadınlar lehine anlamlı şekilde farklılaştığını bulgulamışlardır.

Konya tekstil sektörü çalışanları örneklemli çalışmasında Çevik Tekin ve Akgemci (2017) çalışanların iş tatmin düzeylerinin cinsiyete göre anlamlı şekilde farklılaşı̆̆ı̆ı ve bu farklılığın erkek çalışanlar lehine olduğunu bulgulamıştır. Aynı çalışmada çalsşanların iş tatminlerinin medeni durumlarına göre farklılaşmadığı bulgulanmıştır.

Özaydın ve Özdemir (2014) 244 banka çalışanıyla iş tatmininin cinsiyet ve medeni durumlarına göre farklılı̆ııı araştırdığı çalışmalarında kadın ve erkek çalışanlar arasında iş tatmini düzeyinin farklılaşmadığını, evli çalışanların iç kaynaklı tatmin düzeylerinin bekar çalışanların tatmin düzeyinden anlamlı şekilde yüksek bulgulamışlardır.

\section{2. Örgütsel Stres Kavram1}

Stres Oxford Learners sözlüğü tarafindan "birinin hayatındaki sorunların neden olduğu baskı veya endişe" Türk Dil Kurumu tarafindan "ruhsal gerilim", yönetilemeyen baskılarla başa çıkamama ve bunalmış hissetme durumu (mentalhealth.org.uk) şeklinde tanımlanmaktadır. Stres kavramının tanımı yıllar içinde farklılaşmıştır. Başlangıçta çevre baskısı sonucunda kişinin içindeki gerginlik olarak tanımlanırken günümüzde durum ve birey arasındaki etkileşim olarak tanımlanmaktadır (Michie, 2002). Latince kökenli olan stres, kişilerde dengesizlik ve gerilim nedeni olarak gösterilmektedir (Yllmazer, 2019, s. 197).

Stres kavramı ilk kez 17. yüzyılda fizikçi Robert Hooke tarafından (Yılmazer, 2019), tıp alanında ise ilk kez 1936 yilında Selye tarafindan “ adaptasyon ve hastalık” konulu makalede kullanılmıştır. Bu makale Selye' ye biyolojik stresin babası nitelendirmesini kazandırmıştır (Jackson Ramsden ve Cantor, 2014). Stres, çevresel baskılarla mücadele edilebilmesi için yetersiz kaynaklara sahip olması durumunda oluşan psikolojik ve fiziksel durumdur. Bu psikolojik ve fiziksel durum iş hayatında ortaya çıktı̆ında iş stresi olarak tanımlanmaktadır (Özdemir \& Kerse, 2020). Bireylerde strese neden olan 3 faktörden (bireyin kendisi, çevresi ve işi) birinin örgütsel nedenler (Yllmazer, 2019) olmasına karşın, stresin yönetim bilimleri alanına girişi fizik ve tıp bilimlerine göre daha geç olmuştur. Yönetim literatürüne geç giren stres kavramı, ortaya çıkardığı verimlilik kaygısı nedeniyle bir anda örgütsel çalışmalarda araştırılan en önemli konulardan biri haline gelmiştir (Aydın, 2004, s. 53).

Örgütsel nedenli olarak çalışanlarda yaşanılan psikolojik, fiziksel ve zihinsel zorlanmayla ortaya çıkan tepki (Zencirkıran \& Keser, 2018) olarak tanımlanabilen örgütsel stres; bireylerde yaşanılan en önemli stres kaynağıdır ve bireylerin en fazla fiziksel ve ruhsal zorlanma nedenidir (Şimşek vd., 2020). Gününün çoğunu örgütlerde geçiren bireylerden beklenilen rol ve görevler örgütsel stresin yaratıcısıdır (Pehlivan, 1991, s. 792). Yine örgütün politikaları, yapısal özellikleri, fiziki yapısı ve süreçleri örgütlerde strese neden olan faktörlerin genel başlıklarıdır (Yılmazer, 2019). Cranwell- Ward ve Abbey (2005, ss. 22-23) strese neden olan faktörleri kısaca şu şekilde özetlemiştir:

- Küreselleşmenin ortaya çıkardığı kültürler arası çalışma, farklı saat dilimlerine ve farklı yönetimlere uyum sağlama sorunları

- Zor ekonomik koşullarda, personelin daha az kaynakla daha fazla üretkenliğe ulaşması beklentisi

- Bilişim teknolojisindeki gelişmelerle birlikte iş yaşamının haftanın 7 gününe kayması sonucu sarsılan iş-yaşam dengesi

- İşyerinde yaşanılan zorbalık ve taciz sorunları 
- Uzun çalışma saatleri kültürü, insan yönetimine ilişkin maço yaklaşım şeklinde örgüt kültürünün hakim olduğu örgütler

- Örgütsel değişim

Stresin nedeni ile ilgili yaptığı çalıșmasında Yılmaz ve Ekici (2006) kamu çalıșanlarında en büyük stres kaynağının personel değerlendirmesindeki adaletsizlikler konusu olduğunu bulgulamıştır. Çalışmalarının karşılığını alamama, moral bozukluğu ve ücret yetersizliği çalışanların örgütsel stres nedeni olarak en fazla belirtmiş oldukları durumlardır. Bir başka çalışma sonucunda çalışanların stres kaynağı olarak çalışanın birden fazla amirinin olması, yöneticilerin sürekli başanı beklentisi ve yöneticilerin çalışanların duygusal durumlanyla ilgilenmemesi ve yöneticilerin çok az ilgi göstermesi’ ve yöneticilerin çalışanlarına mesleki konularda yeterli eğitim vermemesi olarak gösterilmiştir (Güllüoğlu, 2012, s. 88)

Stresi tam olarak iyi veya kötü olarak adlandırılmak zordur. Aslında iyi veya kötü olan stresin kendisi değil strese bireyin verdiği tepkinin derecesidir (Arıcan, 2011, s. 58). Bir birey aynı stres faktörüne çok fazla tepki verirken başka bir birey bu durumdan hiç etkilenmemektedir. Bu durum stresin etki derecesinin genel değil öznel bir durum olduğu düşüncesini akla getirmektedir. Stres algılamasının bireysel özelliklere göre farklılaştığı düşüncesi pozitif psikolojik sermaye unsurlanından biri olan kişilerin umut durumu ile de ilişkilendirilmiş ve daha umutlu olan insanların örgütsel stresten daha az etkilendikleri Luthans (2012) tarafından öne sürülmüştür (Urgan, 2019).

Örgütlerde iş gücünün önemli bir bölümünü etkileyen stresin sonucunda bireylerde işe gelmeme, işten ayrılma, alkol ve uyuşturucu bağımlılı̆̆1, saldırganlık, sağlık sorunları ve bezginlik gibi sorunlar oluşabilmektedir (Şimşek vd., 2019, ss. 233-235). İngiltere'de 2008 yllında yaklaşık 415 bin kişi kendilerini hasta edecek düzeyde iş stresi yaşamakta, çalışanların neredeyse beşte biri işlerinin ya "çok stresli" ya da "aşırı derecede stresli" olduğunu düşünmekte ve kişilerin bildirdikleri işle ilgili stres, depresyon ve anksiyete, tahmini 11,4 milyon iş günü kaybına neden olmaktadır (Jenkins, 2010, s. 37).

Stres tüm çalışanları etkileyen bir tehdit olmasının yanında özellikle öğretmenler, hemşireler, barınma ve sosyal yardım görevlileri, müşteri hizmetleri çalışanları gibi bazı meslek gruplarının işyerlerinde daha fazla stres yaşadıkları çalışanlarca dile getirilmektedir (Jenkins, 2010:37). Stres ve hastalık arasında kesin bağlantı anlaşılamamış olsa da bu bağlantının varlığı kabul edilmiş durumdadır (Cranwell-Ward and Abbey, 2005, s. 27). Tip pratisyenleri, polis memurlar1, hapishane memurlar1 ve silahli kuvvetler personeli gibi kamu sektörü güvenliği temelli mesleklere sahip kişilerde yüksek oranda işle ilgili akıl hastalığ1 oranlarına rastlanmaktadır (Jenkins, 2010, s. 37). Bu bağlamda stres özellikle örgütsel düzeyde incelenmesi ve mücadele edilmesi gereken bir sorun olarak karşımıza çıkmaktadır.

\subsubsection{Cinsiyet ve Medeni Durum Değişkenleriyle Örgütsel Stres İlişkisi}

Bireylerde stres düzeyini etkileyen ya da strese neden olan örgütsel faktörlerin yanında kişilik, yaş, cinsiyet, medeni durum gibi bireysel faktörlerde bulunmaktadır (Gümüştekin \& Gültekin, 2009, s. 148). Bu faktörlerden cinsiyet ve medeni durumun örgütsel stres ile ilişkisi pek çok çalışma da araştırılmış ve farklı sonuçlar ortaya konulmuştur.

Çalışma hayatındaki yeri erkeklere göre daha yeni olan kadın çalışanların çalışma hayatındaki yerleri kısmen kabul edilmiş olsa bile, bu kabulün arkasında kadının ev ve topluma karşı sorumluluklarını yerine getirmesi beklentisi halen devam etmektedir. Bu çoklu rol beklentisine ilaveten kadın çalışanların işyerinde yaşadığ1 cinsiyet temelli, ücretlendirme ve terfilerde yaşadığı ayrımcılık, kadınların örgütsel düzlemde mücadelesini daha zorlu hale getirebilmektedir (Haşit \& Yaşar, 2015, s. 6-7). Bu baskılar kadın çalışanların yoğun olarak stres yaşamalarına neden olabilmektedir. Nitekim literatürde bazı çalışma sonuçları da bu durumu desteklemektedir (Doyle \& Hind, 1998; Uzungil \& Yiğit, 2011; Arıcan, 2011; Tinuke, 2015; Agheli vd., 2017; Öztürk \& Kıraç, 2019). Yaman'ın (2020) yaptığ1 tez çalışmasında kadın çalışanların örgütsel stres düzeylerinin erkek çalışanlardan istatistiksel olarak anlamlı şekilde yüksek olduğu tespit edilmiştir. Yine Mantı (2020) tez çalışmasında kadın akademisyenlerin erkek akademisyenlere göre daha yüksek örgütsel stres düzeyine sahip olduğunu bulgulamıştır. Selvi vd.,(2014) 102 adliye çalışanıyla yaptıkları örgütsel stres kaynaklarını araştırdıkları çalışmada stres etkeni olarak görülen yeni durumların ortaya çıkışı kadın çalışanlarca daha fazla örgütsel stres nedeni olarak görülmektedir.

Tinuke (2015) öğretmen, hemşire ve gazetecilerden oluşan 300 katılımcı ile yaptığ1 çalışmasında düşük rütbeli mesleğe sahip kadınların örgütsel stresten erkeklerden daha fazla etkilendiklerini bulgulamıştır. 
McDonald ve Korabik (1991) çalışma hayatında kadınların iş hayatında cinsiyete dayalı ayrımcılık ve engellerden, astları yönetmedeki yaşadıklanı zorluklardan ve ev-iş arasında yaşanılan zorlukları stres kaynağı olarak belirtiklerini ve belirtilen bu etkenlerin erkek çalışanların bildirdiği stres faktörlerinden farklılaştı̆̆ını bildirmiştir. Nelson vd. (1990) kadın İK profesyonellerinin örgüt politikaları nedeniyle erkek meslektaşlarına göre önemli ölçüde daha fazla stres yaşadıklarını bildirmişlerdir (akt. Lim \& Teo, 1996). Omolayo (2012) 25 ile 55 yaş arasındaki genç polis memurlarından oluşan örnekleminde cinsiyetin iş stresi üzerindeki etkisini araştırmıştır. Bu araştırma sonucunda kadın polis memurlarının erkek meslektaşlarından daha yüksek ve anlamlı iş stresi yaşadığı bulgulanmıştır.

Ancak bazı çalışma sonuçlarında ise örgütsel stres düzeyleri arasında kadın ve erkeklerde farklılıklaşmaya rastlanmamıştır (Miller vd., 2000). Örneğin iş stresi ve cinsiyet farklılıkları üzerine yaptı̆̆1 meta-analiz çalışmasında Martocchio ve O'Leary (1989) erkekler ve kadınlar arasında iş stresi açısından anlamlı bir fark bulamamıştır. Beden Eğitimi ve Spor Yüksekokullarında (BESYO) görevli öğretim elemanlarının örgütsel stres düzeylerine etki eden demografik faktörlerin incelendiği çalışmada Yıldırım ve Taşmektepligil (2011) öğretim elemanlarının örgütsel stres düzeyleri ile cinsiyet değişkeni arasında anlamlı farklılaşmaya rastlamamıştır (Yıldırım ve Taşmektepligil, 2011).

Çalışanların medeni durumu da örgütsel stres algısını etkileyebilen bireysel özelliklerden biri olarak karşımıza çıkmaktadır. Evli olan çalısanların sahip oldukları (anne-baba, karı-koca, gelin-damat vb.) oldukları ekstra rollerin onların daha fazla stres yaşamalarına neden olabileceği düşünülmektedir. Literatürde çalışma sonuçları da bu doğrultuda daha çok evli çalışanlar lehine yani evli çalışanların daha çok örgütsel stres yaşadıkları sonucu üzerinde yoğunlaşmaktadır (Emmanuel \& Collins, 2016; Kejriwal, 2019). Yalçın Akgül' ün (2020)'ün çalışma bulgularında evli anestezi uzmanlarının örgütsel stres düzeyleri bekar çalışanlardan anlamlı şekilde yüksek olarak bulgulanmıştır. 228 banka çalışanı örneklemi kullandı̆̆ı çalışmasında Gök (2009) evli çalışanların stres algılarının bekar çalışanlara göre anlamlı şekilde farklılaştı̆ı̆ı bulgulamıştır. Afyonkarahisar ve Antalya'da faaliyet gösteren beş yıldızlı otellerde 465 otel çalışanıyla yaptığı tez çalışmasında Erkılıç (2012) evli çalışanların örgütsel stres algılarının bekar çalışanlardan anlamlı şekilde yüksek olduğunu bulgulamıştır.

\section{Yöntem}

\subsection{Araştırmanın Hipotezleri ve Modeli}

$\mathrm{Bu}$ araştırmanın amacı iş tatminin alg1lanan örgütsel stres etkisinde akademisyenlerin cinsiyetinin ve medeni durumunun düzenleyici rolünü belirlemektir. Bir değişkenin başka bir değişken üzerindeki etkisi bazı bireysel özelliklere göre değişebilmektedir. Düzenleyici değişken (W); bağımlı (Y) ve bağımsız (X) değişken arasındaki ilişkinin yönüne ve şiddetini etkileyebilme gücüne sahip olan değişkendir (Gürbüz, 2019, ss. 81-83). Bu çalısmada iş tatmini ve örgütsel stres ilişkisinde cinsiyet ve medeni durumun düzenleyici rolü araştrılmıştır. Cinsiyet ve medeni durumun hem iş tatmini hem de örgütsel stres üzerinde etkidi daha önce yapılan çalışma sonuçlarıyla ortaya konulmuştur. Hem iş tatmini hem de örgütsel stresi farklılaştıran bu iki değişkenin (cinsiyet ve medeni durum) iş tatmini ve örgütsel stres ilişkisinin yönünü ve şiddetini etkileyerek düzenleyici rol oynayabileceği düşünülmektedir. Bu düşünceden hareketle cinsiyetin ve medeni durumun düzenleyici etkisi ile ilgili aşağıdaki hipotezler ve hipotezi test edecek modeller geliştirilmiştir.

H1. İş tatmininin örgütsel stres etkisinde cinsiyetin düzenleyici rolü vardır. Yani iş tatminin örgütsel stres algısı üzerindeki negatif etkisi kadın ve erkek çalışanlarda farklılaşır.

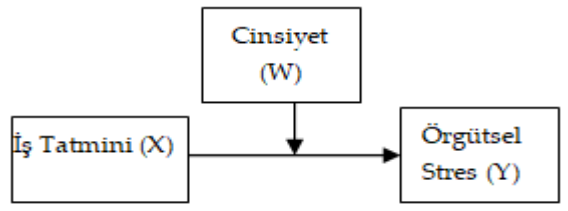

Şekil 1. Test Edilecek Düzenleyicilik Modeli 1

H2. İş tatmininin örgütsel stres etkisinde medeni durumun düzenleyici rolü vardır. Yani iş tatminin örgütsel stres algisı üzerindeki negatif etkisi evli ve bekar çalışanlarda farklılaşır. 


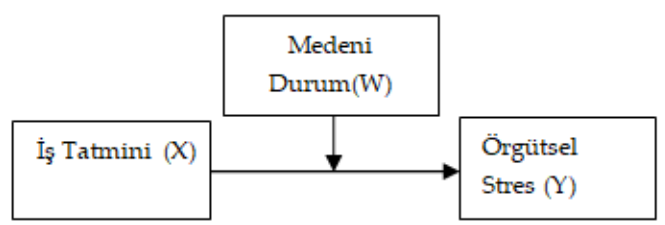

Şekil 2.Test Edilecek Düzenleyicilik Modeli 2

\subsection{Etik İzin}

Çalışmanın etik açıdan uygunluğu ile ilgili Karamanoğlu Mehmetbey Üniversitesi'nin Bilimsel Araştırma ve Yayın Etik Kurulundan 06.07.2020 tarih ve 14490 sayılı yazısıyla izin alınmıstır.

\subsection{Evren ve Örneklem}

Çalışmanın evrenini Karamanoğlu Mehmetbey Üniversitesi' nde (KMÜ) görev yapan akademisyenler oluşturmaktadır. KMÜ 2019 verilerine göre (2020 yllı performans programı) 2019 yllında üniversite bünyesinde 668 akademisyen görev yapmaktadır. Araştırma evreninden $\% 95$ güven düzeyinde $\% 5$ 'lik hata ile yeterli örneklem büyüklüğ̈ 244 olarak belirlenmiştir (surveysystem.com/). Dolayısıyla örneklem sayısı olan 261 evreni temsil edecek büyüklüktedir.

\subsection{Veri Toplama Araçları}

Araştırmada akademisyenlerin iş tatmini ve örgütsel stres düzeyini belirlemede geçerlilikleri ve güvenilirlikleri test edilmiş ölçüm araçları seçilmiştir. Çalışmada kullanılan örgütsel stres ölçeği Theorell vd. (1988) tarafindan geliştirilen Yıldıım vd. (2011) tarafından uyarlanan 17 madde ve 4 boyuttan oluşan ölçektir. Ölçeğin güvenilirliği Yıldırım vd. (2016) tarafından 0,79 olarak hesaplanmıştır. Çalışmada kullanılan iş tatmini ölçeği Hackman ve Oldhamn'a (1975) ait iş özellikleri anketi’ nden Basım ve Şeşen (2009) tarafından uyarlanan tek boyutlu 5 maddeli bir ölçektir. Ölçeğin toplam güvenilirliği Basım ve Şeşen tarafindan 0,78 olarak hesaplanmışır.

\subsection{Verilerin Analizi}

Araştırmada elde edilen verilerin analizinde SPSS programının 22. versiyonu kullanılmıştır. Ölçeklerin geçerlilik ve güvenilirliklerini ortaya koymak için keşfedici faktör analizi ve güvenirlik analizi yapılmıştır. Araştırmanın hipotezleri Hayes tarafından geliştirilen Process Macro (SPSS için) programı kullanılarak analiz edilmiş ve yorumlanmıştır.

\section{Bulgular}

\subsection{Kat1lımc1ların Demografik Özellikleri}

Araştırmaya katulan akademisyenlerin cinsiyet ve medeni durumlarına yönelik veriler Tablo 1'de verilmiştir.

Tablo 1. Demografik Bulgular

\begin{tabular}{clcc}
\hline Değişken & Kategori & Frekans & $\mathbf{( \% )}$ \\
\hline \multirow{2}{*}{ Cinsiyet } & Kadın & 102 & 39,1 \\
& Erkek & 159 & 60,9 \\
\hline Medeni & Evli & 205 & 78,5 \\
Durum & Bekar & 56 & 21,5 \\
\hline Toplam & & 261 & 100 \\
\hline
\end{tabular}

Tablo 1'e göre çalışmaya katılan akademisyenlerin \%60,9’ u erkek, \%39,1’i kadın, \%78,5’i evli, \% 12,5’i ise bekardır.

\subsection{Keşfedici Faktör Analizi (KFA) ve Güvenilirlik Analizi Sonuçları}

Araştırmada akademisyenlerden elde edilen verilerin geçerliklerinin tespit edilmesi için keşfedici faktör analizi yapılmıştır. Keşfedici faktör analizi uygulanması için ön koşullardan biri değişkenlerin normal dağılım göstermesi (Gürbüz \& Şahin, 2018, s. 319) olduğundan ilk olarak normallik analizi yapılmıştır. 
Normallik analizi sonuçlarına göre örgütsel stres (çarpıklık değeri: 0,103, sh=0,100 ve basıklık değeri :$0,356, \mathrm{sh}=0,270)$ ve iş tatmini (çarpıklık değeri: $-0,579, \mathrm{sh}=0,151$; ve basıklık değeri :-0,301, $\mathrm{sh}=0,205$ ) ölçeklerinin çarpıklık ve basıklık değerleri -1 ve +1 değerleri arasında yer aldığı için verilerin normal dağıldığı varsayılmıştır (Kalaycı, 2010, s. 73). Keşfedici faktör analizinde örneklem yeterliliği için KMO değerinin 0,60'dan büyük olması, Barlett Küresellik Testinin ise anlamlı olması $(p<0,05)$ referans olarak alınmıştır (Gürbüz ve Şahin, 2018: 319). KFA' da özdeğerlerin 1'den büyük olması durumunda faktörlerin oluşması sağlanmıştur.

İş tatmini ölçeğinin Kaiser-Meyer-Olkin (KMO) örneklem yeterlilik değeri ,860 ve Barlett küresellik testinin anlamlı olarak $\left(\mathrm{X}^{2}(10)=763,311 \mathrm{p}<.001\right)$ bulgulandığından örneklem sayısının yeterli olduğu ve maddeler arasında korelasyon ilişkilerinin faktör analizi için uygun olduğuna karar verilmiştir (Gürbüz \& Şahin, 2018, s. 330). Analiz sonucunda İş Tatmini Ölçeğinin tek faktörlü yapıda olduğu ve 5 maddelik ölçeğin tek faktörlü yapısının toplam varyansın \%69,407 'sini açıkladığı ve maddelerin faktör yüklerinin 0,7’nin üzerinde olduğu bulgulanmıştır. Tek faktörlü iş tatmini ölçeğinin Cronbach's Alpha güvenilirlik katsayısı 0,883 olarak bulgulanmıştır. Bu sonuçlara göre iş tatmini ölçeğinin geçerli ve güvenilir bir ölçek olduğu bulgulanmıştır.

Örgütsel stres ölçeğinin Keşfedici Faktör Analizi sonucunda Kaiser-Meyer-Olkin (KMO) örneklem yeterlilik değeri $0,736(<0,60)$ ) ve Barlett küresellik testin anlamlı olarak bulgulanmış $\left(X^{2}(78)=1244,551\right.$ $\mathrm{p}<.001)$ ve bu nedenle örneklem büyüklüğünün faktör analizi için yeterli, maddeler arasında korelasyon ilişkilerinin faktör analizi için uygun olduğu tespit edilmiştir (Gürbüz ve Şahin,2018, 330). KFA analizi sonucunda 4, 5 ve 9. maddeler düşük faktör yükü, 6. madde ise düşük güvenil hali 17 maddeden oluşan ölçek 13 maddeli yapıya inmiştir. 13 maddelik ölçeğin 4 faktörlü yapıda olduğu, faktörlerin toplam varyansın \% 66,332'sini açıkladığ1 ve maddelerin faktör yüklerinin 0,4'ün üzerinde olduğu bulgulanmıştır. Araştırma bulgularına göre, ölçeğin açıladığ1 varyansın $(\% 66,332) \% 50$ 'den yüksek olması nedeniyle (Gürbüz ve Şahin, 2018: 321) ölçtüğü niteliği yeterince açıkladığı gözlenmiştir. Ölçeğin Cronbach's Alpha değeri 0,776 olarak bulgulanmıstır.

\subsection{Hipotezlerin Test Edilmesi}

Araştırmada Hayes tarafindan geliştirilen Process Macro (SPSS için) programı hipotezlerinin test edilmesinde kullanılmıştır. Process Macro uygulaması kullandığı bootstrap tekniği araciliğıla düzenleyici etki hesaplanmasında basit ve kullanışlı işlem basamaklarına sahiptir (Gürbüz, 2019, s. 87; Kerse vd., 2020, s. 1775). Akademisyenlerin iş tatminlerinin örgütsel stres algilarnna etkisinde cinsiyetin düzenleyici rolünü test etmek amacıyla Process Makro programı kullanılarak regresyon analizi yapılmıs, sonuçlar Tablo 2'de verilmiştir.

Tablo 2. İş Tatmini, Örgütsel Stres Alg1s1, Cinsiyet Arasındaki Regresyon Analizi Sonuçları

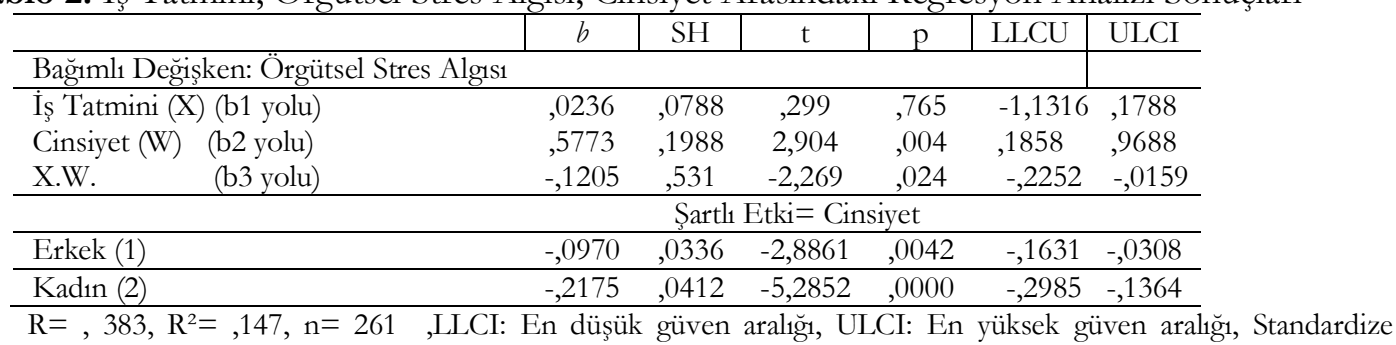

edilmemiş beta katsayıları raporlanmıştır.

Tablo 2'de verilen regresyon analizi sonuçlarına göre regresyon analizine dahil edilen tüm tahmin değişkenlerinin örgütsel stres algisı üzerindeki değişimin $\% 15$ 'ini $\left(\mathrm{R}^{2}=, 147\right)$ açıkladığ görülmüştür. Tablo 2'ye göre iş tatmininin örgütsel stres algısı üzerindeki etkisi (b1 yolu) istatistiksel olarak anlamsızdır $(b=, 0236, \% 95$ GA $[-1,131 ;, 1788], \mathrm{t}=, 299, \mathrm{p}>05)$. Örgütsel stres algisina cinsiyetin etkisi (b2 yolu) ise olumlu yönde anlamlı olarak bulgulanmıştır $(b=, 577, \quad p=<, 05)$. Hipotezimizin desteklenip desteklenmediğini test etmeden önce düzenleyici etkinin anlamlı olup olmadığı analiz edilmiştir. İş tatmini $(\mathrm{X}=$ bağımsız değişken) ile cinsiyet (W= düzenleyici değişken) değişkeninin etkileşimi (X.W) ile ilgili sonuç 
anlamlı olarak bulgulanmıştır ( $b=-, 1205, \% 95$ GA [-,2252; -,0159], $\mathrm{t}=-2,269, \mathrm{p}<05$ ). Düzenleyici etki eğim grafiği incelenerek daha net anlaşılmaktadır. İş tatmininin örgütsel stres algısı üzerindeki etkisinin cinsiyete göre farkl1lık gösterip göstermediğine ilişkin eğim grafiği Şekil 3’te verilmiştir.

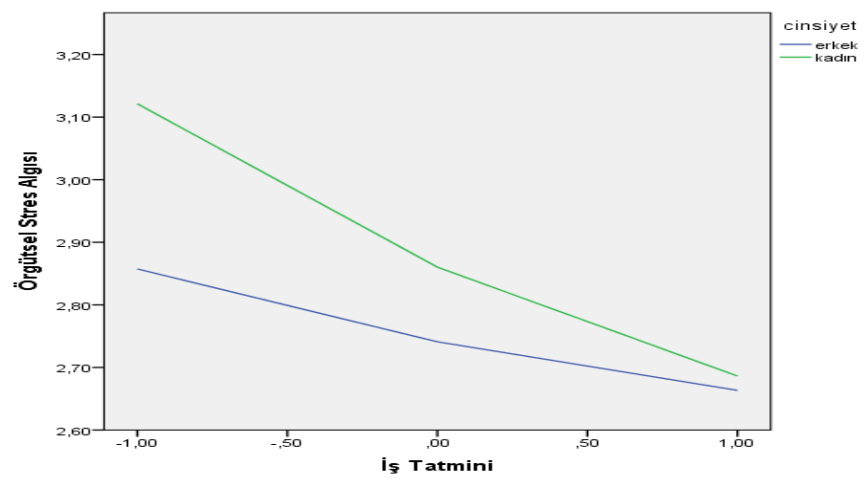

Şekil 3. Cinsiyetin Düzenleyici Rolü (Ĕ̆im Grafiği)

Şekil 3 'te sunulan eğim analizinde sunulan cinsiyetin düzenleyici etkisi incelendiğinde iş tatmininin örgütsel stres algısı üzerindeki negatif etkisinin kadın ve erkek akademisyenlere göre farklllık gösterdiği anlaşılmaktadır. Yani hem kadın hem de erkek akademisyenlerde iş tatmini örgütsel stres algısını etkilemektedir. Ancak kadin akademisyenlerin $(b=-, 2175 ; \% 95$ GA $[-, 2985 ;-, 1364], \mathrm{t}=-5,2852, \mathrm{p}<.001)$ erkek akademisyenlere $(b=-, 0970 ; \% 95$ GA $[-, 1631 ;-, 0308], \mathrm{t}=-2,8861, \mathrm{p}<.05)$ göre iş tatminlerinin örgütsel stres üzerindeki negatif etkisi daha güçlüdür. Bu sonuçlara göre hipotez 1 desteklenmiştir.

Akademisyenlerin iş tatminlerinin örgütsel stres algilarnna etkisinde medeni durumun düzenleyici rolünü test etmek amacıyla yapılan regresyon analizi sonuçları Tablo 3’te verilmiştir.

Tablo 3. İş Tatmini, Örgütsel Stres Algısı, Medeni Durum Arasındaki Regresyon Analizi Sonuçları

\begin{tabular}{|c|c|c|c|c|c|c|}
\hline & $b$ & $\mathrm{SH}$ & $\mathrm{t}$ & $p$ & LLCU & ULCI \\
\hline \multicolumn{7}{|c|}{ Bağ1mlı Değişken: Örgütsel Stres Alg1s1 } \\
\hline İş Tatmini $(\mathrm{X})$ & 1340 & 1406 & 9527 & ,3417 &,- 1430 & ,4109 \\
\hline Medeni Durum (W) (b2 yolu) & ,4171 & ,2871 & 1,4526 & 1476 &,- 1484 & ,9826 \\
\hline X.W. (b3 yolu) &,- 1526 & 0745 & $-2,0493$ & 0415 &,- 2993 &,- 0059 \\
\hline & \multicolumn{6}{|c|}{ Şartlı Etki= Medeni Durum } \\
\hline Bekar (1) &,- 1713 & 0689 &,- 2714 & ,7863 &,- 1543 & ,1169 \\
\hline Evli (2) &,- 0187 &, 0284 & $-6,0309$ & 0000 &,- 2273 &,- 1154 \\
\hline
\end{tabular}

edilmemiş beta katsayları raporlanmıştır.

Tablo 3'te verilen regresyon analizi sonuçlarına göre regresyon analizine dahil edilen tüm tahmin değişkenlerinin örgütsel stres alg1sı üzerindeki değişimin \%13'ünü $\left(\mathrm{R}^{2}=, 134\right)$ açıkladığı görülmüştür. İş tatmininin örgütsel stres alg1sı üzerindeki etkisi (b1 yolu) istatistiksel olarak anlamsızdır ( $B=, 1340, \% 95$ GA [-,1430; ,4109], $\mathrm{t}=, 9527, \mathrm{p}>05$ ). Örgütsel stres algisına medeni durum etkisi (b2 yolu) ise olumlu yönde anlamlı olarak bulgulanmışır $(b=, 4171, p>05)$. İkinci hipotezimizin desteklenip desteklenmediğini test etmeden önce düzenleyici etkinin anlamlı olup olmadığı analiz edilmiştir. İş tatmini ( $\mathrm{X}=$ bağımsız değişken) ile medeni durum ( $\mathrm{W}=$ düzenleyici değişken) değişkeninin etkileşimi (X.W) ile ilgili sonuç anlamlı olarak bulgulanmıştır ( $B=-$, 1526, \%95 GA [-,2993; -,0059], t $=-2,0493, \mathrm{p}<05)$. Düzenleyici etki, eğim grafiği incelenerek daha net anlaşılmaktadır. İş tatmininin örgütsel stres algısı üzerindeki etkisinin medeni duruma göre farkllık gösterip göstermediği Şekil 4'de gösterilmektedir. 


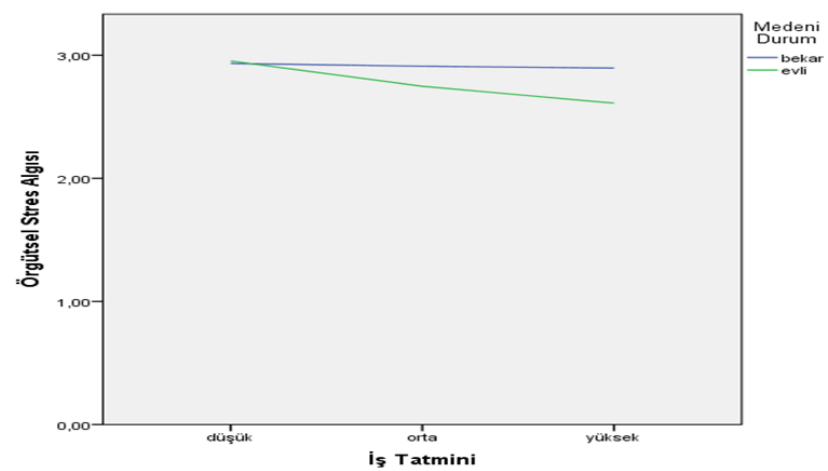

Şekil 4. Medeni Durumun Düzenleyici Rolü (Eğim Grafiği)

Yapılan eğim analizi sonucunda medeni durumun düzenleyici etkisi incelendiğinde iş tatmininin örgütsel stres algisı üzerindeki negatif etkisinin evli ve bekar akademisyenlere göre farkllllı gösterdiği anlaşılmaktadır. Evli akademisyenlerin iş tatmini örgütsel stres algısını anlamlı şekilde etkilerken $(B=$ ,0187; \%95 GA [-,2273; -,1154], $\mathrm{t}=-6,0309 \mathrm{p}<.001)$, bekar akademisyenlerde bu etki anlamlı değildir. $\mathrm{Bu}$ sonuçlara göre Hipotez 2 desteklenmiştir.

\section{Sonuç}

$\mathrm{Bu}$ araştırmada iş tatmininin örgütsel stres algisina etkisinde cinsiyet ve medeni durumun düzenleyici rolü 2 hipotezle belirlenmeye çalışlmıştır. Bu amaç doğrultusunda Karamanoğlu Mehmetbey Üniversitesi'nde görev yapan akademisyenlerden veriler toplanmıştır. Araştırma bulgularına ait sonuçlar ve yorumları aşağıda sunulmuştur.

Akademisyenlerin iş tatminlerinin örgütsel stres algilarına etkisinde cinsiyetin düzenleyici rolünü test etmek amacıyla yapılan regresyon analizi sonuçlarına göre,analize dahil edilen tüm tahmin değisşkenlerinin örgütsel stres algısı üzerindeki değişimin \% 15’ini açıkladığı ve örgütsel stres algısına cinsiyetin etkisinin olumlu yönde anlamlı olduğu bulgulanmışır. İş tatmini ve cinsiyet değişkenlerinin örgütsel stres algisı üzerindeki düzenleyici etkisi anlamlı olarak bulgulanmıştır. Bu sonuca göre iş tatmininin örgütsel stres algısı üzerindeki negatif etkisi kadın ve erkek akademisyenlere göre farklılık göstermekte ve hem kadın hem de erkek akademisyenlerde iş tatmini örgütsel stres algısını etkilemektedir. Ancak kadın akademisyenlerin erkek akademisyenlere göre iş tatminlerinin örgütsel stres algılları üzerindeki negatif etkisi daha güçlü olarak bulgulanmıştır.Örgütsel stres algısını etkileyen örgütsel nedenlere ilaveten pek çok bireysel farklılık da bulunmaktadır. Kadın çalışanların üzerlerine yüklenen ekstra rol beklentilerinin fazla olması ve kadın çalışanların örgütlerinde erkek meslektaşlarının yaşamış olduklanı stres faktörlerine ilaveten cinsiyet temelli yaşadıkları örgütsel stres faktörleri kadınların daha fazla örgütsel stres yaşadıkları yukarda belirtilen çalışma sonuçlarıyla da ispatlanmışıtır. Dolayısıyla kadın çalışanların iş tatmin düzeylerinin örgütsel stres algıları ile daha yoğun bir şekilde ilişkili olması beklenilen bir sonuçtur. Öte yandan örgüt çalışanlarının iş tatminini doğrudan ve negatif bir şekilde etkileyen örgütsel stres algısı tüm çalsşanlar için geçerli bir sonuçtur. Bu doğrultuda erkek akademisyenlerde bu etkiden literatürdeki çalışma sonuçlarıyla (Tyson \& Aggarwal, 2002; Arslan, 2010; Ajayi \& Abimbola, 2013; Emiroğlu vd., 2015) paralel bir şekilde olumsuz bir şekilde etkilenmektedir.

Akademisyenlerin iş tatminlerinin örgütsel stres algilarnna etkisinde medeni durumun düzenleyici rolünü test etmek amacıyla yapılan regresyon analizi sonuçlarına göre analize dahil edilen tüm tahmin değişkenlerinin örgütsel stres alg1sı üzerindeki değişimin \% 13’ünü açlkladığ1, örgütsel stres alg1sina medeni durumun etkisinin olumlu yönde anlamlı olduğu bulgulanmıştır. İş tatmini ve medeni durum değişkenlerinin örgütsel stres algısı üzerindeki düzenleyici etkisi anlamlı olarak bulgulanmıştır. Bu sonuca göre iş tatmininin örgütsel stres algisı üzerindeki negatif etkisi evli ve bekar akademisyenlere göre farklılık göstermektedir. Evli akademisyenlerin iş tatminleri örgütsel stres algısını anlamlı şekilde etkilerken bekar akademisyenlerde bu etki anlamlı değildir. Örgütsel stres ile ilgili yapılan pek çok çalışma bulgusu evli çalışanların örgütsel stresten daha fazla etkilendiği yönündedir (Emmanuel \& Collins, 2016; Kejriwal, 2019; 
Yalçın Akgül, 2020). Dolayısıyla örgütsel stresten evli çalışanların bekar çalışanlara nazaran daha fazla etkilenmeleri iş tatmin düzeylerini de etkileyecektir.

Literatürde yoğun bir şekilde iş tatmini örgütsel stres ilişkisi çalışması yapılırken bu ilişkiye etki edebilecek düzenleyici ve aracı değişkenlerin çok fazla araştırılmadı̆̆ tespit edilmiştir. Literatürde iş tatmini örgütsel stres ilişkisinde cinsiyet ve medeni durumun düzenleyici etkisini araştıran başka bir çalışmaya rastlanılmadığından bu çalışmanın literatüre önemli bir katkı sağlayacağı düşünülmektedir. Ancak çalışma Karamanoğlu Mehmetbey Üniversite'sinde görev yapan akademisyenleri içerdiğinden faklı sektörlerde çalışmanın yapılması farklı sonuçların çıkmasına neden olabilecektir. Dolayısıyla çalışmanın farklı sektörlerde de yapılması önerilmektedir.

\section{Extended Abstract}

The aim of this study is to determine the regulatory role of the gender and marital status of academicians in the perceived organizational stress effect of job satisfaction. It is thought that these two variables (gender and marital status), which differentiate both job satisfaction and organizational stress, may play a regulatory role by affecting the direction and severity of the relationship between job satisfaction and organizational stress. The population of the study consists of 668 academicians working at Karamanoğlu Mehmetbey University (KMU), and the sample consists of 261 academicians. The organizational stress scale used in the study is Theorell et al. (1988) developed by Yildirim et al. (2011), it consists of 17 items and 4 dimensions. Reliability of the scale Yildırım et al. (2016) as 0.79. The job satisfaction scale used in the study is a one-dimensional 5-item scale adapted from Hackman and Oldhamn's (1975) job characteristics questionnaire by Basım and Şeşen (2009). The total reliability of the scale was calculated as 0.78 by Basım and Şeşen. The 22nd version of the SPSS program was used in the analysis of the data obtained in the study. Exploratory factor analysis and reliability analysis were conducted to reveal the validity and reliability of the scales. The hypotheses of the study were analyzed and interpreted using the Process Macro (for SPSS) program developed by Hayes. According to the results of the regression analysis conducted to test the regulatory role of gender in the effect of academicians' job satisfaction on their perceptions of organizational stress, it was found that all predictive variables included in the analysis explained $15 \%$ of the change on organizational stress perception and the effect of gender on organizational stress perception was positively significant. The regulatory effect of job satisfaction and gender variables on perception of organizational stress was found to be significant. According to this result, the negative effect of job satisfaction on the perception of organizational stress differs according to female and male academicians, and job satisfaction affects the perception of organizational stress in both female and male academicians. However, the negative effect of job satisfaction on organizational stress perceptions of female academicians was found to be stronger than male academicians. According to the results of the regression analysis conducted to test the regulatory role of marital status in the effect of academicians' job satisfaction on their perceptions of organizational stress, it was found that all predictive variables included in the analysis explained $13 \%$ of the change on the perception of organizational stress, and the effect of marital status on the perception of organizational stress was significant. The regulatory effect of job satisfaction and marital status variables on perception of organizational stress was found to be significant. According to this result, the negative effect of job satisfaction on the perception of organizational stress differs according to married and single academicians.

\section{Kaynakça}

Agheli, R., Roshangar, F., Parvan, K., Sarbakhsh, P., \&Shafeh, S. (2017). Work stres and organizational citizenship behaviors among nurses. Annals of Tropical Medicine and Public Health, 10(6), 1453.-1458

Ajayi, M. P.,\&Abimbola, O. H. (2013). Job satisfaction, organizational stres and employee performance: A study of NAPIMS. IfePsychologLA: An International Journal, 21(2), 75-82.

Alegre, I., Mas-Machuca, M., \&Berbegal-Mirabent, J. (2016). Antecedents of employee job satisfaction: Do they matter?. Journal of Business Research, 69(4), 1390-1395. 
Asghar, S., \& Oino, D. (2017). Leadership styles and job satisfaction. Asghar, S., \& Oino, I.(2018). Leadership Styles and Job Satisfaction, Market Forces, 13(1), 1-13.

Aşan, Ö., \& Erenler, E. (2008). İş tatmini ve yaşam tatmini ilişkisi. Suleyman Demirel University Journal of Faculty of Economics \& Administrative Sciences, 13(2).

Arıcan, K. (2011). Örgütsel stres kaynakları: kavramsal bir çözümleme: teori ve uygulama. Eğitim ve Insani Bilimler Dergisi, 2, 55-76

Arslan, M. (2010). Calşsma yaşamında stresin iş tatmini üzerindeki etkisi ve bir araștıma. (Yüksek Lisans Tezi) Marmara Üniversitesi Sosyal Bilimler Enstitüsü, İstanbul.

Aydın, Ş. (2004). Örgütsel stres yönetimi. Dokuz Eylül Üniversitesi, Sosyal Bilimler Enstitüsü Dergisi, 6 (3) 49-74.

Azim, M. T.,Haque, M. M., \&Chowdhury, R. A. (2013). Gender, marital status and jobsatisfaction an empirical study. International Review of Management and Business Research, 2(2), 488-498.

Basım, N. \& Şeșen, H. (2009). Örgütsel adalet algısı örgütsel vatandaşllk davramss̆ ilişkisinde is tatmininin arachlle rolu. Osman Gazi Üniversitesi 17. Yönetim ve Organizasyon Kongresi, Eskişehir,21-23 Mayıs, 808-814

Bender, K. A.,Donohue, M., \&Heywood, J. (2005). Jobs atisfaction and genders egregation. Oxford economicpapers, 57(3), 479-496.

Bozkurt, Ö., \& Bozkurt, İ. (2008). İş tatminini etkileyen işletme içi faktörlerin eğitim sektörü açısından değerlendirilmesine yönelik bir alan araştırması. Doğus Üniversitesi Dergisi, 9 (1) 1-18.

Can, Y., \& Soyer, F. (2008). Beden eğitimi öğretmenlerinin sosyo-ekonomik beklentileri ile iş tatmini arasındaki ilişki. Gaæi University Journal of Gaæi Educational Faculty (GUJGEF), 28(1).

Cranwell-Ward, J.,\&Abbey, A. (2005). Organizational Stres, New York: PalgraveMacmillan.

Çevik Tekin, İ. \& Akgemci, T. (2017). Tükenmişliğin İş Tatmini Üzerinde Etkisinin Araştırılması: Konya İli Tekstil Sektöründe Bir Araşturma1. İșletme Araştırmalar Dergisi, 9(4), 400-418.

Çimen, M.,\& Deniz, (2017). Sağhlk Kurumlar Yönetiminde Örgütsel Davramış Konular. Ankara:Sonçăg Matbaacllk ve Yaymallk. Ltd. Sti.

Dar, W. A., \& Najar, I. A. (2017). Job Satisfaction of Plus Two Male Lecturers of District Budgam with Respect to Their Marital Status. International Journal of Multidisciplinary Education and Research, 2-5.

Doyle, C.,\&Hind, P. (1998). Occupational stress, burnout and jobstatus in female academics. Gender, workeorganization, 5(2), 67-82.

Emiroğlu, B. D., Akova, O., \& Tanriverdi, H. (2015). The relationship between turn over intention and demographic factors in hotel businesses: A study at fivestarhotels in Istanbul. Procedia-Social and BehavioralSciences, 207, 385-397.

Emmanuel, A. O.,\&Collins, A. (2016). Relationship between occupational stres and demographic variables: a study of employees in a commercial bank in Ghana. CurrentJournal of AppliedScienceandTechnology, $1-9$.

Erkılıç, E. (2012). Örgütsel stresin örgütsel yabanclaşma üzerine etkisi: beş ynldıð̨h otel işletmelerinde bir araştırma. (Yüksek Lisans Tezi) Afyon Kocatepe Üniversitesi Sosyal Bilimler Enstitüsü, Afyon

Gök, S. (2009). Çalışma yaşamının önemli bir sorunu: Örgütsel stres. Marmara Üniversitesi İktisadi ve İdari Bilimler Dergisi, 27(2), 429-448.

Güllüoğlu, Ö. (2012). Yerel televizyon çalışanlarının örgütsel stres faktörleri: Kayseri ilinde bir araştırma. İstanbul Üniversitesi Illetisim Fakïltesi Dergisi | Istanbul University Faculty of CommunicationJournal, (43), 77-104.

Gümüştekin, G. E.,\& Gültekin, F. (2009). Stres kaynaklarının kariyer yönetimine etkileri. Dumlupınar Üniversitesi Sosyal Bilimler Dergisi, 23(2), 147-158.

Gürbüz, S.,\& Şahin, F. (2018). Sosyal Bilimlerde Araştırma Yöntemleri. (5. Baskı) Ankara: Seçkin Yaymollk.

Gürbüz, (2019). Sosyal Bilimlerde Aracı, Düzenleyici Ve Durumsal Etki Analizleri. Ankara: Seçkin Yaynchlk.

İşcan, Ö. F.,\& Sayın, U. (2010). Örgütsel adalet, iş tatmini ve örgütsel güven arasindaki ilişki. Atatürk Üniversitesi İktisadi ve İdari Bilimler Dergisi, 24(4), 195-216.

Hackman, J. R.,\&Oldham, G. R. (1975). Development of the job diagnostic survey. Journal of Applied psychology, 60(2), 159-170. 
Haşit, G.,\& Yaşar, O. (2015). Çalışan kadınlarda örgütsel stres kaynakları: Bir kamu kurumu örneği. Sakarya İktisat Dergisi, 4(4), 1-30.

Hoşgörür, V.(2018) Motivasyon Kuramlar,Ereş, F. (Ed.), Sosyal Bilimlerde Kuramlar, Ankara: Pegem Akademi, 91-101.

https://www.surveysystem.com/sscalc.htm, Erișim Tarihi: 01.11.2020

https://www.mentalhealth.org.uk/a-to-z/s/stress\#: :text=Stress $\% 20$ can $\%$

20be $\% 20$ defined $\% 20$ as, of $\%$ 20pressures \%20that \%20are\%20unmanageable. Erişim Tarihi: 18.02 .2021

Jackson, M.,Ramsden, E., \&Cantor, D. (2014). EvaluatingThe Role Of HansSelyeIn The Modern History Of Stresin, Rochester: University of Rochester Press.

Jenkins, P (2010), Stres And The Law Weinberg, A., Bond, F., Cooper, C., \&Sutherland, V. J(Ed.) Organizational Stress Management: A Strategic Approach, New York: Palgra and Macmillan, 37-52.

Kalaycı, S.. (2010). SPSS Uygulamal Cok Değiskenli İstatistik Teknikeleri (Vol. 5). Ankara:Asil Yayın Dağıtım.

Karataş, S., \& Güleş, H. (2010). İlköğretim okulu öğretmenlerinin iş tatmini ile örgütsel bağl1llğ́1 arasındaki ilişki. Uşak Üniversitesi Sosyal Bilimler Dergisi, 3(2), 74-89.

Kejriwal, A. (2019). A Comparative Analysis of Organizational Role Stress among the Private and PublicSector Bank Officials in Jorhat, Assam. Journal of Management (JOM), 6(3).

Kerse, G., Koçak, D., \& Özdemir, Ş. (2020) Mütevaz̧ Liderlik Ölçeğinin Türkçe Uyarlaması ve Mütevaz̨ Liderliğin Seslilik Davranısına Etkisi: Kuşak Farkhlı̆̆ımn Düzenleyici Rolü.İşletme Araştırmaları Dergisi, 12(2), 1769-1787.

Kim, H. J.,Tavitiyaman, P., \& Kim, W. G. (2009). The effect of management commitment to service on employee service behaviors: The mediating role of job satisfaction. Journal of Hospitality \& TourismResearch, 33(3), 369-390.

Lim, V. K. G., \& Teo, T. S. H. (1996). Gender differences in occupational stress and coping strategies among IT personnel. Women in Management Review, 11(1), 20-28

Locke, E. A. (1969). What is jobsatisfaction?. Organizationalbehaviorandhumanperformance, 4(4), 309-336.

Mant1, M.(2020). Akademisyenlerde örgütsel stres ve örgütsel sessiz̨lik davranıslar arasindaki ilişki (Yüksek Lisans Tezi), Pamukkale Üniversitesi, Eğitim Bilimleri Enstitüsü, Denizli.

Martocchio, J.L. and O'Leary, A.M., "Sex differences in occupational stress: a meta-analytic review", Journal of Applied Psychology, No. 74, 1989, pp. 495-501

McDonald, L.M. and Korabik, K., "Sources of stress and ways of coping among male and female managers", in Perrewe, P.L. (Ed.), Handbook on Job Stress, Select Press, New York, NY, 1991, pp. 185-99.

Michie, S. (2002). Causes and management of stress at work. Occupational and Environmental Medicine, 59(1), 67-72.

Miller, K., Greyling, M., Cooper, C., Lu, L., Sparks, K., \& Spector, P. E. (2000). Occupational stress and gender: A crosscultural study. Stress Medicine, 16, 271-278.

Omolayo, B. (2012). Effect of gender and status on job stress among police officers in Ekti State of Nigeria. Bangladesh e-Journal of Sociology, 9(1), 38-42.

Oxford Learners Dictionaries, What is Stress? Erişim Adresihttps://www.oxfordlearners dictionaries.com /definition/ english/stress_1?q=stress, Erişim Tarihi: 04.11.2020.

Özaydın, M. M., \& Özdemir, Ö. (2014). Çalışanlanın bireysel özelliklerinin iş tatmini üzerindeki etkileri: Bir kamu bankası örneği. Issletme Arastırmalar Dergisi, 6(1), 251-281.

Özdemir, S., \& Kerse, G. (2020). The Effects of COVID 19 on Health Care Workers: Analysing of the Interaction between Optimism, Job Stress and Emotional Exhaustion. International and Multidisciplinary Journal of Social Sciences, $9(2), 178-201$.

Özpehlivan, M. (2018). İş tatmini: kavramsal gelişimi, bireysel ve örgütsel etkileri, yararlar1 ve sonuçları. Kurklareli Üniversitesi Sosyal Bilimler Dergisi, 2(2), 43-70.

Öztürk Y.E. \& Kıraç R. (2019). Hemşirelerde iş stresi ile iş doyumunun ilişkisi. Erdem R, Bostan S, Şahinöz T.(ed). Uluslararası Sağhk Bilimleri ve Yönetimi Kongresi, İstanbul, 556-561.

Pehlivan, İ. (1991). Örgütsel stres kaynaklar1 ve verimlilik. Ankara Üniversitesi Ë̆itim Bilimleri Fakültesi Dergisi, 24(2), 791-802. 
Rad, A. M. M.,\&Yarmohammadian, M. H. (2006). A study of relationship between managers' leadership style and employees' job satisfaction. Leadership in Health Services, 19 (2), 11-28

Saner, T.,\& Eyüpoğlu, Ş. Z. (2013). The gender-marital status job satisfaction relationship of academic Procedia-Social and Behavioral Sciences, 106, 2817-2821.

Selvi, M. S., Erdem, Y., \& Kayar, Y. (2014). Örgütsel stres kaynaklanı ve baş etme yolları: Tekirdağ adliyesi örneği.BJSS Balkan Journal of Social Sciences / Balkan Sosyal Bilimler Dergisi, 3 (6), 56-75. 502.

Sloane, . J.\& Williams, H. (2000). Jobsatisfaction, comparisonearnings, andgender. Labour, 14(3), 473-

Sevimli, F.,Işscan Ö.F, (2005), Bireysel ve iş ortamına ait etkenler açısından iş doyumu, Ege Akademik Bakız̧ Dergisi. 5( 1-2), 49-68.

Şimşek, M. Şerif, Çelik, A. \&Akgemci, T.(2019) Davranış Bilimlerine Giriş ve Örgütlerde Davramıs. (10. Baskı) Konya: Eğitim Yayınevi

Şimşek, M.Ş., Çelik, A., Akgemci, T. \& Diken, A. (2020). Örgütsel Davranıs ve Yönetim Psikolojisi, Konya: Eğitim Yayınevi.

Theorell, T.,Perski, A., Åkerstedt, T., Sigala, F., Ahlberg-Hultén, G., Svensson, J., \& Eneroth, P. (1988). Changes in jobstrain in relation to changes in physiological state: a longitudinal study. Scandinavianjournal of work, environmenterbealth, 189-196.

Tinuke, M. F. (2015). Gender disparities in antecedents, manifestations and corollaries of workplace stress. Journal of Human Resource Management, 3(6), 60-67.

Tyson, P. D.,Pongruengphant, R., \&Aggarwal, B. (2002). Coping with organizational stres among hospital nurses in Southern Ontario. International journal of nursingstudies, 39(4), 453-459.

TDK, Stres Nedir? Erişim Adresi: https://sozluk.gov.tr/, Erişim Tarihi: 04.11.2020

Urgan, S.,\& Sevim, S.. (2019). Uluslararası Sağhk Kuruluşlarnda, Sosyal Sermaye ve Pozitif Psikolojik Sermaye Etkileşiminde Kültürel Zeka, Konya: Eğitim Yayınevi.

Uzun, Ö., \& Yiğit, E. (2011). Örgütsel stres ve örgütsel bağlllık ilişkisi üzerine orta kademe otel yöneticileri üzerinde yapılan bir araştırma. Eskişebir Osmangað̧ Üniversitesi IIBBF Dergisi, 6(1), 181-213

Yalçın Akgül, G. (2020). Ameliyathane çalşsanlarmm örgütsel stres dü̈eyleri ile basta güvenlik, tutumlar arasindaki ilişskinin belirlenmesi. (Yüksek Lisans Tezi), Akdeniz Üniversitesi, Sağılk Bilimleri Enstitüsü, Antalya.

Yaman, U. (2020). Örgütsel stres ve kurum içi iletisim algularmm çalışan performansina etkisi (Yüksek Lisans Tezi), Ege Üniversitesi, Sosyal Bilimler Enstitüsü, İzmir.

Yazıcıoğlu, İ. (2010). Örgütlerde iş tatmini ve işgören performansı ilişkisi: Türkiye ve Kazakistan karşılaştırmasi. bilig, 55(1), 243-264.

Yıldırım, Y.,Taşmektepligil, M. Y., Üzüm, H. ve Bulut, D. (2011). Kısa versiyon Örgütsel Stres Ölçeğinin Türkçe'ye uyarlanması (geçerlilik ve güvenirlik çalışması). Selçuk Üniversitesi Beden Eğitimi ve Spor Bilimleri Dergisi, 13(1), 103-108.

Yılmaz, A.,\& Ekici, (2006). Örgütsel yaşamda kamu çalışanlarının örgütsel stres kaynakları üzerine bir araştırma. Süleyman Demirel Üniversitesi İktisadi ve İdari Bilimler Fakëlltesi Dergisi, 11(1), 31-58.

Yilmazer, A. (2019).Stres ve Stres Yönetimi, Yılmazer, A. (Ed.), Davrams Bilimlerine Giriş Ve Örgütsel Davranıs, Ankara: Detay Yayıncilık, 197-209.

Wright, T. A. (2006). The emergence of job satisfaction in organizational behavior. Journal of Management History. 12 (3), 262-27

Weinberg, A., Bond, F., Cooper, C., \&Sutherland, V. J. (2010). Organizational Stress Management: A Strategic Approach. New York: Palgra ve Macmillan.

Zencirkıran, M.,\& Keser, A. (2018). Örgütsel Davranıs, Değerlemesi ve Yönetimi. Bursa: Dora Basım Yayın. 